\title{
Ozonolysis of some 8-alkoxyquinolines, and synthesis of a precursor to the non-sedating antihistamine Claritin
}

\author{
Mathias C. Eichler and David H. Grayson* \\ School of Chemistry, Trinity Biomedical Sciences Institute, Trinity College Dublin,152-160 \\ Pearse Street, Dublin 2, Ireland \\ E-mail: dgrayson@tcd.ie
}

DOI: http://dx.doi.org/10.3998/ark.5550190.p008.843

\begin{abstract}
3-Formyl-2-methoxycarbonylpyridine and isopropyl 3-formylpyridine-2-carboxylate have each been efficiently accessed in one step via the ozonolyses of 8-methoxy- or of 8-isopropoxyquinoline under near-ambient conditions. The compounds can be utilized as intermediates for syntheses of the tricyclic ketone 8-chloro-6,11-dihydro-5H-benzo[5,6]cyclohepta[1,2- $b]$ pyridin11-one, a precursor to the important non-sedating antihistamine Claritin.
\end{abstract}

Keywords: Alkoxyquinoline, ozonolysis, pyridine, aldehyde, ester

\section{Introduction}

Ethyl 4-(8-chloro-5,6-dihydro-11H-benzo[5,6]cyclohepta[1,2-b]pyridin-11-ylidene)piperidine-1carboxylate $\mathbf{1}$, is a widely-utilised non-sedating anti-histaminic, anti-allergenic drug that is structurally somewhat related to the tricyclic antidepressants. The compound $\mathbf{1}$ is sold under trade names such as Claritin, ${ }^{1}$ Clarityn $^{2}$ and Loratadine. Sales of 1 during 2001 exceeded US \$3 billion, making it the fourth-largest selling drug in the world for that year. ${ }^{3}$ The drug became a generic product in the USA at the end of 2002, but the $\$$ value of global sales is now far lower than it was. An interesting history of the discovery of Claritin has been published. ${ }^{4}$ 


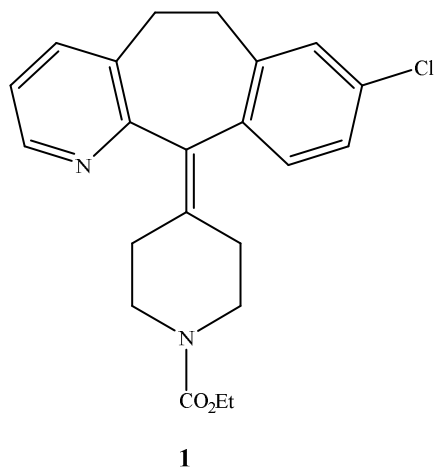

There is an extensive literature that describes synthetic routes to Claritin 1. Thus (Scheme 1), an initial disclosure ${ }^{5}$ was followed by others, ${ }^{6,7,8}$ each of which broadly described Claisen-like condensations between an alkyl 3-picolinate $\mathbf{2}$ and the anion derived from the benzylic nitrile $\mathbf{3}$ to give the keto-nitrile 4 .<smiles>CC(=O)c1cccnc1</smiles><smiles>N#CCc1cccc(Cl)c1</smiles>

3<smiles>N#CC(C(=O)c1cccnc1)c1cccc(Cl)c1</smiles><smiles>[O-][n+]1cccc(CCc2cccc(Cl)c2)c1</smiles>

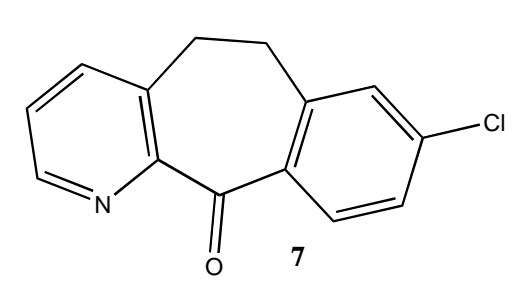

Scheme 1. Early routes to the key tricyclic ketone $7 .^{5-8}$

This was then subjected to series of manipulations to yield the $N$-oxide $\mathbf{5}$, which underwent a Reissert-Henze reaction to deliver the pyridyl nitrile $\mathbf{6}$. Hydrolysis of $\mathbf{6}$ to the derived carboxylic 
acid was followed by Friedel-Crafts ring-closure to give the key tricyclic intermediate 7. Hydrogen peroxide may ${ }^{9}$ be substituted for $m$-CPBA for N-oxidation of the pyridine ring, but the conversion of keto-nitrile 4 into the $N$-oxide 5 by the laborious removal of two activating groups followed by the introduction of another, and the subsequent insertion into the pyridine moiety of a cyano group via Reissert-Henze chemistry are all unproductive or unattractive steps that are preferably avoided.

Recognising this, Schumacher et al. ${ }^{10}$ later (Scheme 2) devised an improved route to Claritin $\mathbf{1}$ in which the lithiated pyridyl amide $\mathbf{8}$ was initially alkylated to give $\mathbf{9}$, a precursor for the nitrile 6.

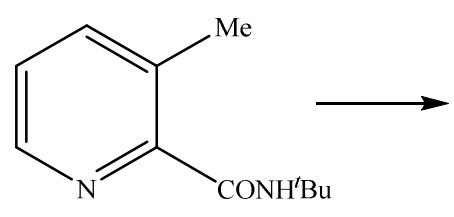

8

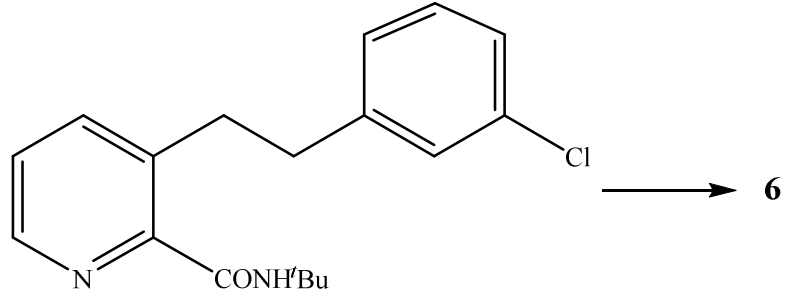

9

Scheme 2. Second-generation route to the intermediate nitrile $\mathbf{6}^{10}$

In more recent developments ${ }^{11,12}$ amides such as $\mathbf{1 0}$ have been obtained (Scheme 3) by Pdmediated aminocarbonylation of 2-bromo-3-methylpyridine 11. Lithiation of $\mathbf{1 0}$ at low temperature, and alkylation of the derived anion using 5-chloro-2-iodobenzyl bromide gave the diarylethane 12, which was converted into the tricyclic ketone 7 via transmetallation of the iodo function (using $\mathrm{RMgX}$ or RLi) and subsequent cyclo-acylation.<smiles>Cc1cccnc1Br</smiles>

11

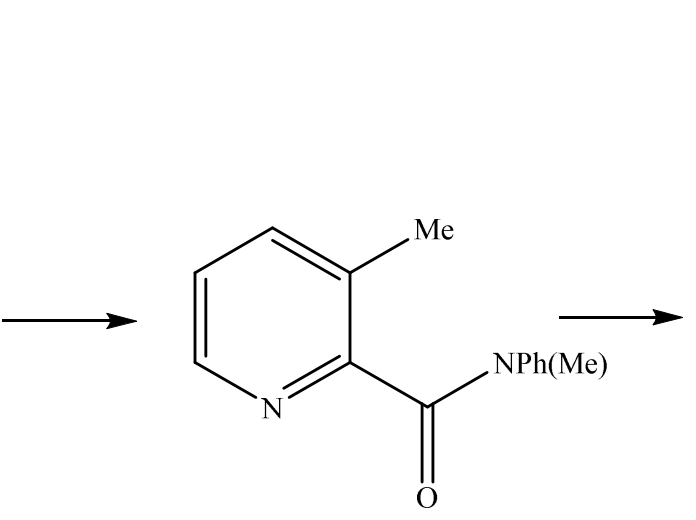

10<smiles>CCNC(=O)c1ncccc1CCc1cc(Cl)ccc1I</smiles>

12

\section{Scheme 3}


A variant on this route ${ }^{13,14}$ involves the intramolecular cyclisation of a secondary amide $\mathbf{1 3}$ using strongly acidic catalysts such as $\mathrm{P}_{2} \mathrm{O}_{5}-\mathrm{CF}_{3} \mathrm{SO}_{3} \mathrm{H}$ to give an imine that is then hydrolysed to yield the ketone 7 .<smiles>O=Cc1ncccc1CCc1cccc(Cl)c1</smiles>

$13 \mathrm{R}=\mathrm{NHR}^{\prime}$

$15 \mathrm{R}=\mathrm{OH}$<smiles>Cc1cccnc1C(=O)O</smiles>

14<smiles>Cc1cccnc1C1=NC(C)(C)CO1</smiles>

It has been reported ${ }^{15}$ that 3-methylpyridine-2-carboxylic acid 14 reacts smoothly with two equivalents of LDA, even at ambient temperatures, to give a dianion that is $C$-alkylated by 3 chlorobenzyl chloride to yield the acid $\mathbf{1 5}$, which can then be cyclised to give $\mathbf{7}$. Similarly, the dihydrooxazoline 16 can be mono-lithiated at the 3-methyl group and then alkylated using 3chlorobenzyl chloride to give ${ }^{16}$ another precursor of the tricyclic ketone 7.

\section{Results and Discussion}

In devising possible alternative routes to Claritin 1, the financial and pharmaceutical potency of which was earlier apparent, it appeared to us that the regioselective ozonolysis of suitable quinoline derivatives under environmentally benign conditions might provide useful differentially functionalised pyridines that would be potentially valuable synthons for the key tricyclic ketone intermediate 7.

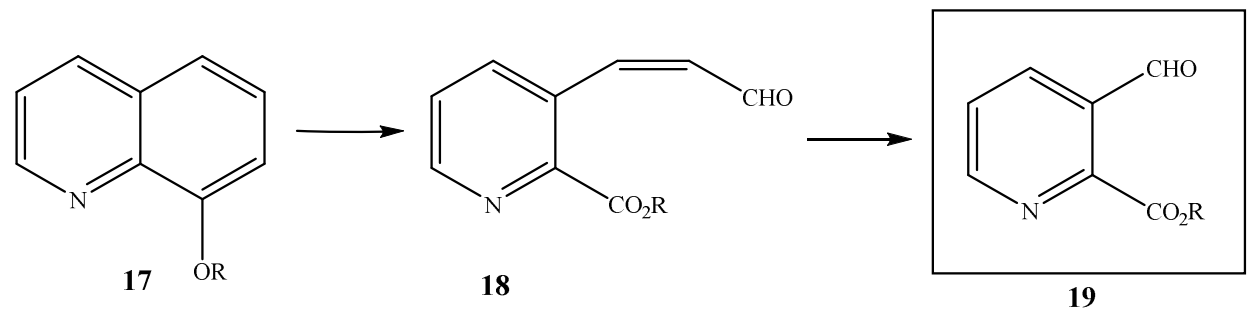

Scheme 4. Selective ozonolysis of an 8-alkoxyquinoline

We considered (Scheme 4) that in an ether 17 derived from 8-hydroxyquinoline, the electronrich aryl ring would undergo preferential oxidative cleavage by ozone leaving the more electrondeficient pyridine ring intact and provide, via secondary cleavage of the (Z)-enal 18, a 2- 
carboxyalkylpyridine-3-carboxaldehyde 19 that might then be converted into the key tricyclic ketone 7.

Some early studies on the exhaustive degradative ozonolysis of alkylquinolines were carried out during the 1940s by Schenck and Bailey. ${ }^{17,18}$ More controlled experiments ${ }^{19}$ with a number of substituted quinolines that included 8-hydroxyquinoline $\mathbf{2 0}$ showed that the initial reaction with ozone took place on the benzenoid ring, and that oxidative work-up yielded pyridine 2,3dicarboxylic acid 21 (5-95\%). Pyridine-2,3-dicarboxaldehyde 22 has ${ }^{20}$ also been obtained via ozonolysis of quinoline, but yields were very low $(<3 \%)$. It was later shown ${ }^{20-22}$ that the pyridyl ring of quinoline was also attacked by ozone, but only to a minor extent.<smiles>Oc1cccc2cccnc12</smiles>

20<smiles>[R]c1ncccc1C(=O)O</smiles>

$21 \mathrm{R}=\mathrm{CO}_{2} \mathrm{H}$ $23 \mathrm{R}=\mathrm{H}$<smiles>O=Cc1cccnc1C=O</smiles>

22

Quinoline has been converted into pyridine-3-carboxylic acid $\mathbf{2 3}$ by a procedure involving ozonolysis in aqueous nitric acid, ${ }^{23}$ but ozonolysis of pyridine in neutral aqueous tert-butanol gives $^{24}$ the derived $\mathrm{N}$-oxide and this type of reaction represents a potential threat to yields where ozonolysis of quinolines to give pyridine free bases is concerned. However, it has been reported ${ }^{25}$ that a number of vinylpyridines can be ozonised at $-40{ }^{\circ} \mathrm{C}$ in methanol to give modest yields of the derived pyridine carboxaldehydes after reduction of the ozonides with sodium sulfite.

Surprisingly, the literature is almost totally silent regarding the ozonolysis of 8alkoxyquinolines. In a solitary example it has been reported ${ }^{26}$ that 3-ethyl-8-methoxyquinoline is ozonised to yield 5-ethylpyridine-1,2-dicarboxylic acid. The oxidative work-up used in this case clearly precluded the isolation of any aldehyde as product. More recently, Taddei et al. have described $^{27}$ the successful ozonolysis of three substituted 5-alkoxyquinolines to yield keto-esters as cleavage products in yields ranging from $39-45 \%$.

We initially carried out the ozonolysis of 8-methoxyquinoline 24 in methanol at $0{ }^{\circ} \mathrm{C}$, using triethylamine to reduce the ozonide that was formed. However, only minor amounts of the desired aldehydo-ester 25 were produced, together with some of the diester 26. The outcome (Scheme 5) was completely different if dimethyl sulfide (which has been recommended ${ }^{28}$ as being a superior reagent for the reduction of ozonides) was used instead of triethylamine, when the aldehyde 25 was isolated in good (81\%) yield. 


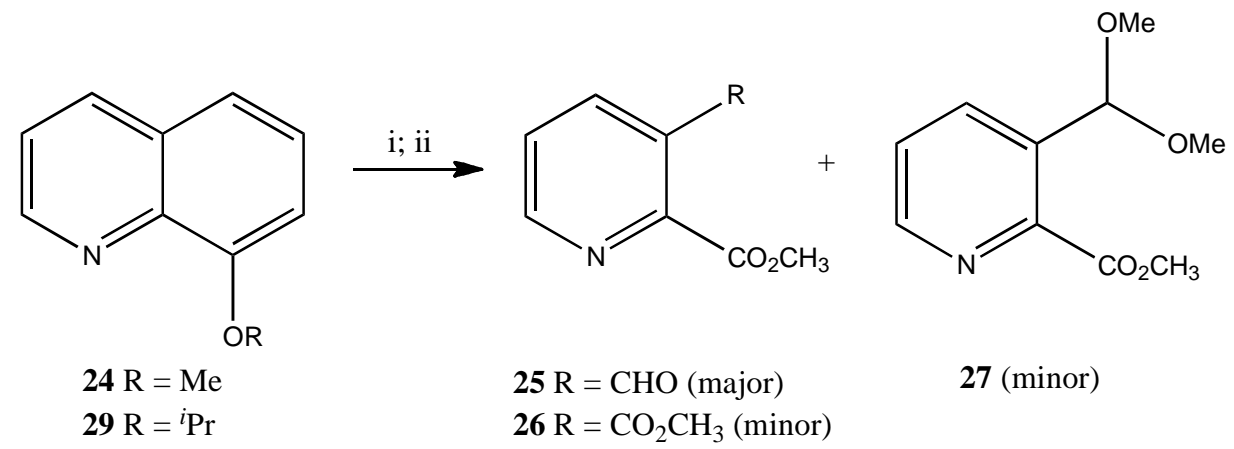

Scheme 5. Ozonolysis of 8-methoxyquinoline. Reagents: (i) $\mathrm{O}_{3} / \mathrm{MeOH}$; (ii) $\mathrm{Me}_{2} \mathrm{~S}$

A by-product formed during the ozonolysis of 8-methoxyquinoline $\mathbf{2 4}$ was the dimethyl acetal 27. This may be the source of another minor by-product, the diester $\mathbf{2 6}$, since ozone is known to oxidise acetals to esters. ${ }^{29}$<smiles>CC(=O)c1ncccc1C=CC=O</smiles>

28<smiles>CCOC(=O)c1ncccc1C=O</smiles>

30

If the ozonolysis of 8-methoxyquinoline 24 at $0{ }^{\circ} \mathrm{C}$ in methanol was interrupted before the calculated amount of ozone had been passed into the reaction mixture the $(E)$ - and $(Z)$-isomers of the unsaturated aldehyde $\mathbf{2 8}$ could be isolated. These could not be separated by column chromatography because whenever this was attempted the $(Z$ )-form of $\mathbf{2 8}$ underwent conversion into the $(E)$-isomer, a process that may occur because of traces of acid in the silica gel that was used. The formation of $\mathbf{2 8}$ under ozone-limiting conditions is not entirely unexpected, since this reflects initial attack by ozone at the most electron-rich $\mathrm{C}-\mathrm{C}$ bond of 8-methoxyquinoline $\mathbf{2 4}$. Similar partial ozonolysis reactions of naphthalene have been reported. ${ }^{30,31}$

8-Isopropoxyquinoline 29 was also successfully ozonised in methanol at $0{ }^{\circ} \mathrm{C}$ to give the expected aldehydo-ester $\mathbf{3 0}$ in excellent yield after reductive work-up using dimethyl sulfide. An alternative multi-step synthesis of this compound from quinolinic anhydride has been described, ${ }^{32}$ but the overall yield obtained using that route was only $c a .20 \%$. 
<smiles>PCc1cccc(Cl)c1</smiles>

$31 \mathrm{R}=\mathrm{PO}(\mathrm{OEt})_{2}$ $33 \mathrm{R}=\mathrm{Ph}_{3} \mathrm{P}^{+} \mathrm{Cl}^{-}$ (i) $\mathrm{BuLi}$

(ii)<smiles>O=Cc1cccnc1C(=O)O</smiles><smiles>[R]OC(=O)c1ncccc1C=Cc1cccc(Cl)c1</smiles>

Scheme 6. Wittig olefination of the aldehydes $\mathbf{2 5}$ and $\mathbf{3 0 .}$

With easy access to large quantities of the aldehydo-esters $\mathbf{2 5}$ and 30 in hand we next explored olefination reactions of the aldehyde 25. A Horner-Emmons reaction that was attempted between the aldehydo-ester $\mathbf{2 5}$ and the anion of the benzylic phosphonate $\mathbf{3 1}$ afforded a complex mixture of products from which the desired stilbazole 32 could not be isolated. However (Scheme 6), Wittig olefination of aldehyde 25 using the ylide derived from the phosphonium salt $\mathbf{3 3}$ gave a separable mixture of the $(E)$ - and $(Z)$-isomers of $\mathbf{3 2}$.

If unpurified aldehyde 25, obtained directly from the ozonolysis of 8-methoxyquinoline 24, was used in this Wittig reaction, methyl (E)-3-(3-chlorophenyl)prop-2-enoate $\mathbf{3 4}$ could be isolated as an additional minor component during chromatography of the product mixture. The precursor to this must be methyl glyoxylate, most likely formed via further reaction of ozone with the initially-formed mono-ozonide that leads from 8-methoxyquinoline to the $\alpha, \beta$ unsaturated aldehyde $\mathbf{2 8}$.

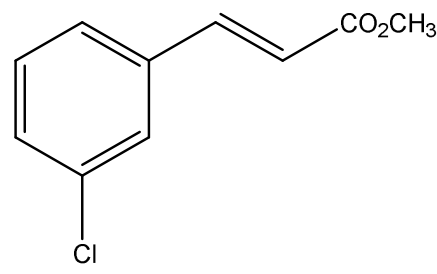

34<smiles>[R]Oc1ncccc1CCc1cccc(Cl)c1</smiles>

$35 \mathrm{R}=\mathrm{CH}_{3}$ $37 \mathrm{R}={ }^{i} \mathrm{Pr}$

Hydrogenation of $(E)-/(Z)-32$ led to the ethane derivative 35, which was readily hydrolysed to give the pivotal target acid 15.

The isopropyl ester 30 was similarly converted by Wittig olefination into the corresponding stilbazole $(E) /(Z)-\mathbf{3 6}$. Hydrogenation of $\mathbf{3 6}$ gave $\mathbf{3 7}$, which was also hydrolysed to yield the acid 
15. Conventional intramolecular cyclisation of the acid 15, via its acyl chloride, then delivered the targeted tricyclic ketone 7.

\section{Conclusions}

The useful pyridine aldehydo-esters $\mathbf{2 5}$ and $\mathbf{3 0}$ have been efficiently obtained from inexpensive 8-alkoxyquinolines via simple and relatively "green" ozonolysis reactions carried out under nearambient conditions. These accessible and differentially-functionalised pyridines have been utilised in syntheses of the tricyclic ketone 7, which is a precursor of the non-sedating antihistamine Claritin, and should find other applications in the field of heterocyclic chemistry.

\section{Experimental Section}

General. Unless otherwise stated, ${ }^{1} \mathrm{H}$ and ${ }^{13} \mathrm{C}$ NMR spectra were recorded for solutions in $\mathrm{CDCl}_{3}$ using a Bruker Avance DPX $400 \mathrm{MHz}$ spectrometer. Coupling constants are recorded in $\mathrm{Hz}$. Assignments were verified where appropriate by ${ }^{1} \mathrm{H}-{ }^{1} \mathrm{H} \operatorname{COSY},{ }^{1} \mathrm{H}_{-}{ }^{13} \mathrm{C}$ COSY, DEPT and HMBC experiments. IR spectra were recorded for Nujol mulls (N) or liquid films (L) between sodium chloride plates using a Mattson FT-IR spectrometer. Mass spectra were obtained under electrospray conditions using a Micromass time-of-flight instrument. Melting points (uncorrected) were measured in unsealed capillary tubes using an Electrothermal IA9100 apparatus. Thin layer chromatography was carried out using Merck Kieselgel $60 \mathrm{~F}_{254} 0.2 \mathrm{~mm}$ silica gel plates. Column chromatography was carried out using Merck Kieselgel 60 (70-230 mesh) silica gel. Ozonolysis was carried out using a BOC Mark 2 apparatus. All solvents were dried and distilled before use. Organic extracts of reaction products were dried over anhydrous magnesium sulfate.

8-Methoxyquinoline (24). 8-Hydroxyquinoline (4.6 g; $31.7 \mathrm{mmol})$ and anhydrous potassium carbonate $(10.1 \mathrm{~g} ; 73.1 \mathrm{mmol})$ in DMF $(60 \mathrm{~mL})$ were stirred under $\mathrm{N}_{2}$ at $90{ }^{\circ} \mathrm{C}$ for $1 \mathrm{~h}$ after which time dimethyl sulfate (TOXIC! $3 \mathrm{~mL} ; 31.7 \mathrm{mmol}$ ) was added and the mixture was stirred for a further $2 \mathrm{~h}$ at $90{ }^{\circ} \mathrm{C}$. The cooled mixture was then diluted with water $(300 \mathrm{~mL})$ and extracted using dichloromethane. The combined organic layers were washed with aqueous potassium hydroxide solution $(5 \% ; 100 \mathrm{~mL})$ in portions, and then with water until the washings were no longer alkaline. The extract was dried, filtered and evaporated to give 8methoxyquinoline 24 (2.67 g; 53\%), obtained as an oily solid (lit. ${ }^{33} \mathrm{mp} 46-47^{\circ} \mathrm{C}$ ) of sufficient purity for further use, $v_{\max }$ (L) 3391, 3051, 3005, 2955, 2903, 2837, 1616, 1597, 1572, 1501, 1472, 1440, 1424, 1378, 1317, 1263, 1224, 1194, 1174, 1111, 1077, 1031, 994, 823, 792, 753 and $711 \mathrm{~cm}^{-1} ; \delta_{\mathrm{H}} 4.07\left(3 \mathrm{H}, \mathrm{s}, \mathrm{OCH}_{3}\right), 7.04(1 \mathrm{H}, \mathrm{d}, J 8$ and $H-7), 7.35-7.5(3 \mathrm{H}, \mathrm{m}, H-3, H-5$ and $H-6), 8.11(1 \mathrm{H}, \mathrm{dd}, J 8$ and $1.5, H-4)$ and $8.91(1 \mathrm{H}, \mathrm{dd}, J 4.2$ and $1.8, H-2) \mathrm{ppm}$. 
Ozonolysis of 8-methoxyquinoline 24: 3-formyl-2-methoxycarbonylpyridine (25). A threenecked flask $(250 \mathrm{~mL})$ fitted with a stirring bar and a dropping funnel was placed in an ice-bath and connected to the ozoniser. 8-Methoxyquinoline 24 (5.7 g; $35.8 \mathrm{mmol})$, dissolved in methanol $\left(100 \mathrm{~mL}\right.$ ), was added and the solution was subjected to a stream of ozonised $\mathrm{O}_{2}$ (containing $\left.\sim 1.5 \% \mathrm{O}_{3}\right)$ for $2 \mathrm{~h}\left(\mathrm{O}_{2}\right.$-flow rate of $\left.1 \mathrm{~L} / \mathrm{min}\right)$. Ozone production was discontinued and the system was flushed with $\mathrm{O}_{2}$ for 20 min to purge excess reagent. Dimethyl sulfide $(6.6 \mathrm{~mL} ; 90 \mathrm{mmol})$ was slowly added via the dropping funnel while the stirred mixture was continuously cooled in an ice-bath. After a further $30 \mathrm{~min}$, solvents were removed under reduced pressure, the viscous brown oil obtained was taken up in ethyl acetate $(100 \mathrm{~mL})$ and the extract was washed with brine and dried. Evaporation of the solvent gave crude 3-formyl-2-carbomethoxypyridine 25 (4.8 g; $81 \%$ ) which could be used without further purification in the following Wittig reaction. An analytical sample of the aldehyde 25 was obtained by extracting the crude oily product using petroleum ether (bp 40-60 ${ }^{\circ} \mathrm{C}$ ). 3-Formyl-2-methoxycarbonylpyridine 25 crystallised from the cooled extract and was recrystallised from petroleum ether to give analytically pure material as colourless plates, $\operatorname{mp} 82-83{ }^{\circ} \mathrm{C}, v_{\max }(\mathrm{N}) 2953,2924,2854,1710,1693,1578,1460,1426,1377$, $1318,1263,1196,1177,1088,1056,944,850,819,801,722$ and $709 \mathrm{~cm}^{-1} ; \delta_{\mathrm{H}}\left(\right.$ DMSO- $\left.d_{6}\right) 3.94$ $\left(3 \mathrm{H}, \mathrm{s}, \mathrm{CO}_{2} \mathrm{CH}_{3}\right), 7.81(1 \mathrm{H}, \mathrm{dd}, J 7.8$ and $4.8, H-5), 8.31(1 \mathrm{H}, \mathrm{dd}, J 7.8$ and $1.8, H-4), 8.87(1 \mathrm{H}$, $\mathrm{dd}, J 5$ and $1.5, \mathrm{H}-6)$ and $10.31(1 \mathrm{H}, \mathrm{s}, \mathrm{CHO}) \mathrm{ppm} ; \delta_{\mathrm{C}}\left(\mathrm{DMSO}-d_{6}\right) 52.95\left(\mathrm{CO}_{2} \mathrm{CH}_{3}\right), 126.61(C-$ 5), $131.07(C-3), 137.56(C-4), 149.72(C-2), 152.93(C-6), 165.73\left(C_{2} \mathrm{CH}_{3}\right)$ and $191.68(C \mathrm{HO})$ ppm. HRMS $m / z$ 166.0502. Calc. for $\left[\mathrm{C}_{8} \mathrm{H}_{7} \mathrm{NO}_{3}+\mathrm{H}\right]^{+}: 166.0504$.

In some cases where ${ }^{1} \mathrm{H}$ NMR analysis of the crude product revealed significant amounts of impurities, the mixture was chromatographed over silica gel (EtOAc/hexane). In this way, samples of the by-products $\mathbf{2 6}$ and $\mathbf{2 7}$ were isolated and characterised.

Dimethyl pyridine-2,3-dicarboxylate 26 had mp 54-56 ${ }^{\circ} \mathrm{C}$ (EtOAc) ( lit. ${ }^{34} \mathrm{mp} 55-56{ }^{\circ} \mathrm{C}$ ), $v_{\max }(\mathrm{N})$ 3458, 3162, 3082, 3026, 3010, 2960, 2852, 1736, 1723, 1574, 1451, 1432, 1304, 1286, 1262, $1225,1196,1139,1081,1057,958,845,782,763$ and $731 \mathrm{~cm}^{-1} ; \delta_{\mathrm{H}} 3.94\left(3 \mathrm{H}, \mathrm{s}, \mathrm{CO}_{2} \mathrm{CH}_{3}\right), 4$ $\left(3 \mathrm{H}, \mathrm{s}, \mathrm{CO}_{2} \mathrm{CH}_{3}\right), 7.5(1 \mathrm{H}, \mathrm{dd}, J 7.8$ and $4.8, H-5), 8.18(1 \mathrm{H}, \mathrm{dd}, J 7.5$ and $1.5, H-4)$ and 8.77 (1H, d, $J$ 4, H-6) ppm

Methyl 3-(1',1'-dimethoxymethyl)pyridine-2-carboxylate 27 was obtained as an oil, $v_{\max }(\mathrm{L})$ $3057,2995,2953,2835,1735,1639,1575,1450,1427,1353,1302,1249,1197,1133,1119$, $1082,984,964,909,886,834,807,759$ and $712 \mathrm{~cm}^{-1} ; \delta_{\mathrm{H}} 3.36\left(6 \mathrm{H}, \mathrm{s}, \mathrm{OCH}_{3}\right.$ groups), $3.97(3 \mathrm{H}$, s, $\left.\mathrm{CO}_{2} \mathrm{CH}_{3}\right), 6\left(1 \mathrm{H}, \mathrm{s}, \mathrm{CH}\left(\mathrm{OCH}_{3}\right)_{2}\right), 7.44(1 \mathrm{H}, \mathrm{dd}, J 8$ and $4.8, H-5), 8.06(1 \mathrm{H}, \mathrm{dd}, J 8$ and $1.5, H-$ 4) and $8.62(1 \mathrm{H}, \mathrm{d}, \mathrm{J} 4, \mathrm{H}-6) \mathrm{ppm} ; \delta_{\mathrm{C}} 52.3\left(\mathrm{CO}_{2} \mathrm{CH}_{3}\right), 53.63\left(\mathrm{CH}\left(\mathrm{OCH}_{3}\right)_{2}\right), 99.32\left(\mathrm{CH}\left(\mathrm{OCH}_{3}\right)_{2}\right)$, 125.15 (C-5), $134.29(C-3), 135.51(C-4), 147.17(C-2), 148.21(C-6)$ and $165.95\left(C_{2} \mathrm{CH}_{3}\right)$ ppm. HRMS $m / z$ 212.0911. Calc. for $\left[\mathrm{C}_{10} \mathrm{H}_{13} \mathrm{NO}_{4}+\mathrm{H}\right]^{+}: 212.0923$.

Interrupted ozonolysis of 8-methoxyquinoline 24: (Z)- and (E)-3-(2methoxycarbonylpyridin-3-yl)prop-2-enal (28). A three-necked flask $(250 \mathrm{~mL})$ fitted with a stirring bar and a dropping funnel was placed in an ice-bath and connected to the ozoniser. 8Methoxyquinoline 24 (7.09 g; $44.6 \mathrm{mmol})$, dissolved in methanol $(100 \mathrm{~mL})$, was added and the solution was subjected to a stream of ozonised $\mathrm{O}_{2}$ (containing $\left.\sim 1.5 \% \mathrm{O}_{3}\right)$ for $3 \mathrm{~h}\left(\mathrm{O}_{2}\right.$-flow rate 
of $0.5 \mathrm{~L} / \mathrm{min}$ ). Ozone production was discontinued and the system was flushed with $\mathrm{O}_{2}$ for 20 min to purge excess reagent. Dimethyl sulfide $(9.0 \mathrm{~mL} ; 122.7 \mathrm{mmol})$ was slowly added via the dropping funnel while the stirred mixture was continuously cooled in an ice-bath. After a further $60 \mathrm{~min}$, solvents were removed under reduced pressure, the viscous brown oil obtained was taken up in ethyl acetate $(100 \mathrm{~mL})$ and the extract was washed with brine and dried. Evaporation of solvent gave the crude product mixture as an oil $(4.9 \mathrm{~g})$ of which a portion (1.6 g) was chromatographed over silica gel using EtOAc - hexane as eluant. One fraction so obtained ( 0.4 g) was rechromatographed using EtOAc - hexane to give pure (E)-3-(2methoxycarbonylpyridin-3-yl)prop-2-enal $(\boldsymbol{E})$-28 as a solid, mp 117-118 ${ }^{\circ} \mathrm{C}$ (EtOAc/hexane), $v_{\max }(\mathrm{N})$ 2904, 2728, 2672, 1710 (overlapping $\mathrm{C}=\mathrm{O}$ absorptions), 1580, 1461, 1377, 1312, 1298, $1237,1196,1120,1085,968,860,821,797,722,707$ and $685 \mathrm{~cm}^{-1} ; \delta_{\mathrm{H}} 4.06\left(3 \mathrm{H}, \mathrm{s}, \mathrm{CO}_{2} \mathrm{CH}_{3}\right)$, $6.65(1 \mathrm{H}, \mathrm{dd}, J 16$ and $7.5, H-2), 7.58\left(1 \mathrm{H}, \mathrm{dd}, J 8\right.$ and 4.5, $\left.H-5{ }^{\prime}\right), 8.04(1 \mathrm{H}$, dd, $J 8$ and 1.5, $H$ 4'), $8.38(1 \mathrm{H}, \mathrm{d}, J 16, H-3), 8.78(1 \mathrm{H}, \mathrm{dd}, J 4.5$ and $1.5, H-6 ')$ and $9.81(1 \mathrm{H}, \mathrm{d}, J 7.5, H-1) \mathrm{ppm}$; $\delta_{\mathrm{C}} 52.82\left(\mathrm{CO}_{2} \mathrm{CH}_{3}\right), 126.29\left(C^{-} 5^{\prime}\right), 131.51\left(C-3^{\prime}\right), 132.07(C-2), 135.5\left(C-4^{\prime}\right), 145.86\left(C-2^{\prime}\right)$, $147.59(C-6), 150.21(C-3), 165.26\left(C_{2} \mathrm{CH}_{3}\right)$ and $192.87(C-1)$ ppm. HRMS $m / z, 192.0663$. Calc. for $\left[\mathrm{C}_{10} \mathrm{H}_{9} \mathrm{NO}_{3}+\mathrm{H}\right]^{+}$: 192.0661. (Z)-3-(2-methoxycarbonylpyridin-3-yl)prop-2-enal (Z)-28 could never be separated by column chromatography but was clearly present in the crude ozonolysis mixture and had $\delta_{\mathrm{H}} 3.96\left(3 \mathrm{H}, \mathrm{s}, \mathrm{CO}_{2} \mathrm{CH}_{3}\right), 6.26(1 \mathrm{H}, \mathrm{dd}, J 11.8$ and 8, H-2), 7.52 $\left(1 \mathrm{H}, \mathrm{dd}, J 7.8\right.$ and 4.7, H-5'), $7.72\left(1 \mathrm{H}, \mathrm{d}, J 7.5, H-4^{\prime}\right), 8.08(1 \mathrm{H}, \mathrm{d}, J 11.5, H-3), 8.75(1 \mathrm{H}, \mathrm{d}, J$ $4.5, H-6 ')$ and $9.62(1 \mathrm{H}, \mathrm{d}, J 8.5, H-1) \mathrm{ppm}$.

8-Isopropoxyquinoline (29). 8-Hydroxyquinoline (14 g; $96.4 \mathrm{mmol}$ ) and anhydrous potassium carbonate $(34.6 \mathrm{~g} ; 250 \mathrm{mmol})$ in DMF $(150 \mathrm{~mL})$ were stirred under $\mathrm{N}_{2}$ at $80{ }^{\circ} \mathrm{C}$ for $75 \mathrm{~min}$ after which time 2-bromopropane $(23.5 \mathrm{~mL} ; 250 \mathrm{mmol})$ was slowly added in two portions. The mixture was stirred at $80{ }^{\circ} \mathrm{C}$ for another $3 \mathrm{~h}$ and then the cooled contents of the flask were diluted with water $(500 \mathrm{~mL})$ and extracted with dichloromethane. The combined organic extracts were washed with aqueous potassium hydroxide solution $(5 \% ; 200 \mathrm{~mL})$ in portions and then with water until the washings were no longer alkaline. The dried and filtered extract was evaporated, leaving 8-isopropoxyquinoline 29 (13 g; $85 \%$ ) as a viscous oil (lit. ${ }^{35} \mathrm{mp} 41-43{ }^{\circ} \mathrm{C}$ ), $v_{\max }$ (L) 3458, 3162, 3082, 3026, 3010, 2960, 2852, 1736, 1723, 1574, 1451, 1432, 1304, 1286, 1262, $1225,1196,1139,1081,1057,958,845,782,763$ and $731 \mathrm{~cm}^{-1} ; \delta_{\mathrm{H}} 1.55(6 \mathrm{H}, \mathrm{d}, J 6$, $\left.\mathrm{OCH}\left(\mathrm{CH}_{3}\right)_{2}\right), 4.87\left(1 \mathrm{H}\right.$, septet, $J$ 6, OCH $\left.\left(\mathrm{CH}_{3}\right)_{2}\right), 7.09(1 \mathrm{H}, \mathrm{d}, J$ 7.5, H-7), $7.35-7.5(3 \mathrm{H}, \mathrm{m}, H-3$, $H-5$ and $H-6), 8.13(1 \mathrm{H}, \mathrm{dd}, J 8$ and $1.5, H-4)$ and $8.98(1 \mathrm{H}, \mathrm{dd}, J 4$ and $1.5, H-2) \mathrm{ppm}$.

Ozonolysis of 8-isopropoxyquinoline 29: isopropyl 3-formylpyridine-2-carboxylate (30). A three-necked flask $(250 \mathrm{~mL})$ fitted with a stirring bar and dropping funnel was placed in an icebath and connected to the ozoniser. 8-Isopropoxyquinoline 29 (13.0 g; $69.4 \mathrm{mmol})$, dissolved in methanol $(150 \mathrm{~mL})$, was added and the solution was subjected to a stream of ozonised $\mathrm{O}_{2}$ (containing $\left.\sim 1.5 \% \quad \mathrm{O}_{3}\right)$ during $4.5 \mathrm{~h}\left(\mathrm{O}_{2}\right.$ flow rate of $\left.2 \mathrm{~L} / \mathrm{min}\right)$. Ozone production was discontinued and the system was flushed with $\mathrm{O}_{2}$ for $20 \mathrm{~min}$ to purge excess reagent. Dimethyl sulfide $(13 \mathrm{~mL} ; 177.3 \mathrm{mmol})$ was slowly added via the dropping funnel while the mixture was continuously cooled in an ice-bath. After a further $30 \mathrm{~min}$ solvents were removed under reduced 
pressure. The viscous brown oil so obtained was taken up in ethyl acetate $(100 \mathrm{~mL})$ and the extract was washed with brine and dried. The crude oily product (13.4 g; 99\%) was used without further purification for olefination reactions, but an analytical sample of the aldehyde $\mathbf{3 0}$ was obtained by column chromatography (EtOAc/hexane) as an oil (lit. ${ }^{32}$ an oil) that had $v_{\max }(\mathrm{N})$ 3068, 2985, 2935, 2879, 1736, 1711, 1579, 1468, 1456, 1439, 1387, 1375, 1344, 1304, 1265, $1240,1186,1146,1103,1088,916,881,868,841,822,802,762$ and $714 \mathrm{~cm}^{-1} ; \delta_{\mathrm{H}} 1.46(6 \mathrm{H}, \mathrm{d}, J$ 6, $\left.\mathrm{OCH}\left(\mathrm{CH}_{3}\right)_{2}\right), 5.4\left(1 \mathrm{H}\right.$, septet, $\left.J 6.3, \mathrm{OCH}\left(\mathrm{CH}_{3}\right)_{2}\right) 7.6(1 \mathrm{H}, \mathrm{dd}, J 7.8$ and $4.8, H-5), 8.26(1 \mathrm{H}$, $\mathrm{dd}, J 7.8$ and $1.8, H-4), 8.89(1 \mathrm{H}, \mathrm{dd}, J 4.5$ and $1.5, H-6)$ and $10.58(1 \mathrm{H}, \mathrm{s}, \mathrm{CHO}) \mathrm{ppm}$.

Wittig olefination of aldehyde 25: methyl $(E)$ - 3-(2-(3-chlorophenyl)ethenyl)pyridine-2-

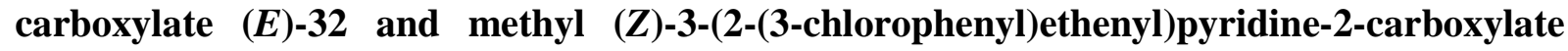
(Z)-32. 3-Chlorobenzyltriphenylphosphonium bromide $3^{36}$ (2.4 g; $\left.5.1 \mathrm{mmol}\right)$ was dissolved under $\mathrm{N}_{2}$ in freshly distilled anhydrous THF $(50 \mathrm{~mL})$ at $0{ }^{\circ} \mathrm{C}$ and treated with $n$-butyllithium (2.5M in hexane: $2 \mathrm{~mL} ; 5 \mathrm{mmol}$ ). After $30 \mathrm{~min}$ the temperature was decreased to $-78{ }^{\circ} \mathrm{C}$ and the aldehyde 25 ( $0.8 \mathrm{~g}$; $4.8 \mathrm{mmol})$, dissolved in THF $(10 \mathrm{~mL})$, was added. After $1 \mathrm{~h}$ the mixture was warmed to room temperature and stirring was continued overnight. It was then diluted with water $(100 \mathrm{~mL})$ and extracted with chloroform. The extract was dried, filtered and evaporated to give a mixture of the $(E)$ - and $(Z)$-isomers of the stilbazole 32, which were separated by column chromatography (EtOAc/hexane).

Methyl (E)-3-(2-(3-chlorophenyl)ethenyl)pyridine-2-carboxylate $(\boldsymbol{E})-32$ had mp 73-74 ${ }^{\circ} \mathrm{C}$ (EtOAc/hexane), $v_{\max }(\mathrm{N})$ 2953, 2922, 2852, 1730 (C=O), 1589, 1456, 1377, 1306, 1281, 1238, 1194, 1140, 1099, 1078, 991, 976, 966, 910, 889, 866, 858, 822, 810, 802, 777, 723, 712, 683 and $675 \mathrm{~cm}^{-1} ; \delta_{\mathrm{H}} 3.95\left(3 \mathrm{H}, \mathrm{s}, \mathrm{CO}_{2} \mathrm{CH}_{3}\right), 6.86\left(1 \mathrm{H}, \mathrm{d}, J 16, H-2^{\prime}\right), 7.14-7.23\left(2 \mathrm{H}, \mathrm{m}, H_{-}{ }^{\prime \prime}\right.$ and $H_{-}-$ 5"), $7.32(1 \mathrm{H}, \mathrm{dt}, J 7$ and 1.5 and $1.5, H-6 "), 7.37(1 \mathrm{H}, \mathrm{dd}, J 8$ and $4.5, H-5), 7.42(1 \mathrm{H}, \mathrm{d}, J 2, H-$ 2"), $7.82\left(1 \mathrm{H}, \mathrm{d}, J 16.6, H-1{ }^{\prime}\right), 7.94(1 \mathrm{H}, \mathrm{dd}, J 8$ and $1.5, H-4)$ and $8.53(1 \mathrm{H}, \mathrm{d}, J 3.5, H-6) \mathrm{ppm}$; $\delta_{\mathrm{C}} 52.42\left(\mathrm{CO}_{2} \mathrm{CH}_{3}\right), 124.65(C-6 "), 125.31\left(C-1^{\prime}\right), 125.89,126.31$ ( $C-5$ and $\left.C-2^{\prime \prime}\right), 127.78\left(C-4^{\prime \prime}\right)$, 129.46 (C-5"), 131.33 (C-2'), 133.96, 134.15 (C-3 and $C-3 "), 134.37$ (C-4), 138.01 (C-1"), 145.01 (C-2), $147.71(C-6)$ and $165.74\left(\mathrm{CO}_{2} \mathrm{CH}_{3}\right)$ ppm. HRMS $\mathrm{m} / \mathrm{z}$ 274.0634. Calc. for $\left[\mathrm{C}_{15} \mathrm{H}_{12} \mathrm{ClNO}_{2}+\mathrm{H}\right]^{+}: 274.0635$.

Methyl (Z)-3-(2-(3-chlorophenyl)ethenyl)pyridine-2-carboxylate (Z)-32 had $\mathrm{mp} \mathrm{50-51}{ }^{\circ} \mathrm{C}$ (EtOAc/hexane), $v_{\max }(\mathrm{N}) 3384,3188,2954,2924,2854,1718(\mathrm{C}=\mathrm{O}), 1707,1593,1560,1456$, 1412, 1377, 1302, 1282, 1242, 1200, 1142, 1088, 958, 920, 899, 877, 833, 818, 793, 750, 704, 687 and $661 \mathrm{~cm}^{-1} ; \delta_{\mathrm{H}} 3.9\left(3 \mathrm{H}, \mathrm{s}, \mathrm{CO}_{2} \mathrm{CH}_{3}\right), 6.61\left(1 \mathrm{H}, \mathrm{d}, J 12, H-2^{\prime}\right), 6.81(1 \mathrm{H}, \mathrm{d}, J 7.5, H-4 ")$, 6.95-7.01 (3H, m, H-1', H-2" and H-5"), $7.04(1 \mathrm{H}, \mathrm{d}, J 8, H-6 ") 7.17(1 \mathrm{H}, \mathrm{dd}, J 7.8$ and 4.7, H-5), $7.43(1 \mathrm{H}, \mathrm{dd}, J 7.5$ and $1, H-4)$ and $8.52(1 \mathrm{H}, \mathrm{d}, J 4.5, H-6) \mathrm{ppm} ; \delta_{\mathrm{C}} 52.21\left(\mathrm{CO}_{2} \mathrm{CH}_{3}\right), 125.3$ (C-5), 126.75 (C-4"), 126.93 (C-6"), 128.07, 128.52, 129.01 (C-1', $C-2^{\prime \prime}$ and $\left.C-5 "\right), 129.61\left(C-2^{\prime}\right)$, 133.66, 134.21 (C-3 and $C-3 "), 137.31$ (C-1"), 138.75 (C-4), $145.88(C-2), 147.84(C-6)$ and $165.41\left(\mathrm{CO}_{2} \mathrm{CH}_{3}\right)$ ppm. HRMS $\mathrm{m} / z$ 274.0646. Calc. for $\left[\mathrm{C}_{15} \mathrm{H}_{12} \mathrm{ClNO}_{2}+\mathrm{H}\right]^{+}: 274.0635$.

If the unpurified aldehyde $\mathbf{2 5}$, obtained from the ozonolysis of 8-methoxyquinoline $\mathbf{2 4}$, was used for the above Wittig reaction, methyl (E)-3-(3-chlorophenyl)prop-2-enoate $\mathbf{3 4}$ could be isolated as an additional minor component during chromatography of the product mixture. This, a low- 
melting solid (lit. ${ }^{37} \mathrm{mp} 45-46.5^{\circ} \mathrm{C}$ ), had $v_{\max }$ (N) 3063, 2952, 2925, 2852, 1722, 1641, 1595, $1568,1467,1435,1376,1317,1201,1174,1106,1979,1038,1015,982,884,860,788,744$ and $673 \mathrm{~cm}^{-1} ; \delta_{\mathrm{H}} 3.83\left(3 \mathrm{H}, \mathrm{s}, \mathrm{CO}_{2} \mathrm{CH}_{3}\right), 6.46(1 \mathrm{H}, \mathrm{d}, J 16, H-2), 7.3-7.43\left(3 \mathrm{H}, \mathrm{m}, H-4{ }^{\prime}, H-5^{\prime}\right.$ and $\left.H-6^{\prime}\right), 7.52\left(1 \mathrm{H}, \mathrm{s}, H-2^{\prime}\right)$ and $7.64(1 \mathrm{H}, \mathrm{d}, J 16, H-3) \mathrm{ppm} ; \delta_{\mathrm{C}} 51.41\left(\mathrm{OCH}_{3}\right), 118.8(C-2), 125.8$ $\left(C-6^{\prime}\right), 127.34\left(C-2^{\prime}\right), 129.69,129.71\left(C-4^{\prime}\right.$ and $\left.C-5^{\prime}\right), 134.46\left(C-3^{\prime}\right), 135.72\left(C-1^{\prime}\right), 142.8(C-3)$ and $166.57(C-1) \mathrm{ppm}$.

Hydrogenation of methyl $(E)$ - and (Z)-3-(2-(3-chlorophenyl)ethenyl)pyridine-2carboxylates 32: methyl 3-(2-(3-chlorophenyl)ethanyl)pyridine-2-carboxylate (35). A mixture of $(E)$ - and $(Z)$-isomers of the stilbazole $32(0.4 \mathrm{~g} ; 1.33 \mathrm{mmol})$ was dissolved in ethyl acetate $(10 \mathrm{~mL})$ and $5 \% \mathrm{Pd} / \mathrm{C}$ catalyst $(20 \mathrm{mg})$ was added. The mixture was hydrogenated at 1 atm. until reaction was complete $(\sim 4 \mathrm{~h})$. Catalyst was removed by filtration and solvent was evaporated to give the ester $\mathbf{3 5}$ as a solid that was recrystallised from ethyl acetate/hexane (0.36 $\mathrm{g} ; 89 \%), \mathrm{mp} 54-55{ }^{\circ} \mathrm{C}$ (EtOAc/hexane), $v_{\max }(\mathrm{N}) 3066,3053,2953,2922,2852,1726$ (C=O), 1718, 1599, 1572, 1477, 1464, 1456, 1444, 1429, 1377, 1306, 1294, 1259, 1234, 1201, 1136, $1097,1076,968,889,868,849,820,804,769,725,702$ and $683 \mathrm{~cm}^{-1} ; \delta_{\mathrm{H}} 2.94\left(2 \mathrm{H}, \mathrm{m}, H-2^{\prime}\right)$, $3.25\left(2 \mathrm{H}, \mathrm{m}, H-1^{\prime}\right), 4.02\left(3 \mathrm{H}, \mathrm{s}, \mathrm{CO}_{2} \mathrm{CH}_{3}\right), 7.07(1 \mathrm{H}, \mathrm{dd}, J 6.5$ and $2, H-6 "), 7.18-7.26(3 \mathrm{H}, \mathrm{m}, H-$ 2", $H-4 "$ and $H-5 "), 7.38(1 \mathrm{H}, \mathrm{dd}, J 7.8$ and $4.8, H-5), 7.54(1 \mathrm{H}, \mathrm{dd}, J 8$ and $1.5, H-4)$ and 8.61 $(1 \mathrm{H}, \mathrm{dd}, J 4.5$ and $1.5, H-6) \mathrm{ppm} ; \delta_{\mathrm{C}} 34.55\left(C-1^{\prime}\right), 36.61\left(C-2^{\prime}\right), 52.37\left(\mathrm{CO}_{2} C_{3}\right), 125.68(C-5)$, 125.93, 126.39, 128.24, 129.23 (C-2", $C-4 ", C-5$ " and $C-6 "), 133.7$ (C-3"), $138.18(C-3), 139.12$ $(C-4), 142.58(C-1 "), 146.38(C-2), 146.88(C-6)$ and $165.79\left(C_{2} \mathrm{CH}_{3}\right)$ ppm. HRMS $\mathrm{m} / \mathrm{z}$ 276.0798. Calc. for $\left[\mathrm{C}_{15} \mathrm{H}_{14} \mathrm{ClNO}_{2}+\mathrm{H}\right]^{+}: 276.0791$.

Hydrolysis of methyl 3-(2-(3-chlorophenyl)ethanyl)pyridine-2-carboxylate 35 to 3-(2-(3chlorophenyl)ethanyl)pyridine-2-carboxylic acid (15). The methyl ester 35 (0.36 g; 1.31 mmol) was dissolved in ethanol $(5 \mathrm{~mL})$ with sodium hydroxide $(0.2 \mathrm{~g})$ and water $(20 \mathrm{~mL})$ and the mixture was stirred during $48 \mathrm{~h}$. It was then acidified using $1 \mathrm{M} \mathrm{HCl}$ and extracted with chloroform. The organic layer was washed with brine, dried, filtered and evaporated to yield a colourless solid that was recrystallised from ethyl acetate to afford $0.3 \mathrm{~g}(88 \%)$ of the acid 15, $\operatorname{mp~} 125-126{ }^{\circ} \mathrm{C}^{38} v_{\max }$ (N) 3475, 3192, 3078, 2953, 2924, 2854, 1658, 1601, 1572, 1508, 1460, 1431, 1377, 1358, 1313, 1290, 1167, 1151, 1103, 1088, 1076, 1057, 1022, 995, 955, 891, 872, $849,835,800,779,692,681$ and $661 \mathrm{~cm}^{-1} ; \delta_{\mathrm{H}}\left(\mathrm{DMSO}-d_{6}\right) 2.87\left(2 \mathrm{H}, \mathrm{m}, H-2^{\prime}\right), 3.1\left(2 \mathrm{H}, \mathrm{m}, H-1^{\prime}\right)$, $7.18(1 \mathrm{H}, \mathrm{d}, J$ 7.5, H-6"), 7.26 (1H, d, J 7.8, H-4"), 7.28-7.35 (2H, m, H-2" and $H-5 "), 7.49(1 \mathrm{H}$, dd, $J 7.8$ and $4.8, H-5), 7.78(1 \mathrm{H}, \mathrm{dd}, J 7.5$ and $1, H-4), 8.5(1 \mathrm{H}, \mathrm{dd}, J 4.8$ and $1.2, H-6)$ and $13.16\left(1 \mathrm{H}, \mathrm{s}, \mathrm{CO}_{2} H\right) \mathrm{ppm} ; \delta_{\mathrm{C}} 33.74\left(C-1^{\prime}\right), 36.11\left(C-2^{\prime}\right), 125.78(C-5), 126.02,127.08,128.21$, 130.18 (C-2", $C-4 ", C-5^{\prime \prime}$ and $\left.C-6 "\right), 132.94(C-3 "), 136.3$ (C-3), 139.1 (C-4), 143.77 (C-1"), $146.68(C-6), 148.65(C-2)$ and $167.58(C=\mathrm{O})$ ppm. HRMS $m / z$ 262.0620. Calc. for $\left[\mathrm{C}_{14} \mathrm{H}_{12} \mathrm{ClNO}_{2}+\mathrm{H}\right]^{+}: 262.0635$.

Wittig olefination of aldehyde 30: isopropyl $(E)$ - and (Z)-3-(2-(3chlorophenyl)ethenyl)pyridine-2-carboxylates (36). 3-Chlorobenzyltriphenylphosphonium bromide $^{36} 33$ (14 g; $30 \mathrm{mmol}$ ) was dissolved under $\mathrm{N}_{2}$ in freshly-distilled anhydrous THF (60 $\mathrm{mL})$ at $0{ }^{\circ} \mathrm{C}$. To this solution was added $n$-butyllithium $(2.5 \mathrm{M}$ in hexane: $12 \mathrm{~mL} ; 30 \mathrm{mmol})$ and 
stirring was continued for $30 \mathrm{~min}$. The temperature was reduced to $-70{ }^{\circ} \mathrm{C}$ and 3 -formyl-2isopropoxycarbonylpyridine 30 (5.8 g; $30 \mathrm{mmol})$, in THF $(10 \mathrm{~mL})$, was added. After $30 \mathrm{~min}$ the mixture was warmed to room temperature and stirring was continued for a further $6 \mathrm{~h}$. The mixture was diluted with water $(200 \mathrm{~mL})$, extracted using diethyl ether and the extract was dried, filtered and evaporated. Ether $(50 \mathrm{~mL})$ was added to the residue and the mixture was stirred and heated for $1 \mathrm{~h}$ and then filtered to remove insoluble triphenylphosphine oxide. The filtrate was evaporated and the oily residue was chromatographed (diethyl ether) to give a yellow oil (4.02 g; $44 \%$ ) consisting mainly of the $(E)$ - and $(Z)$-isomers of the stilbazole 36. An analytical sample of the $(E)$-isomer could be obtained by further column chromatography (EtOAc/hexane) but the $(Z)$-isomer was always contaminated by traces of the $(E)$-form.

Isopropyl $(\boldsymbol{E})$-3-(2-(3-chlorophenyl)ethenyl)pyridine-2-carboxylate $(\boldsymbol{E})$-36 was obtained as a solid that had $\mathrm{mp} 82-84{ }^{\circ} \mathrm{C}$ (EtOAc/hexane), $v_{\max }$ (L) 2923, 2853, 2361, 2343, 1712, 1637, 1610, 1593, 1561, 1506, 1459, 1377, 1353,1293, 1243, 1181, 1148, 1106, 1087, 1060, 956, 909, 870, 850, 806, 772, 737, 709 and $678 \mathrm{~cm}^{-1} ; \delta_{\mathrm{H}} 1.49\left(6 \mathrm{H}, \mathrm{d}, J 6.2, \mathrm{CH}\left(\mathrm{CH}_{3}\right)_{2}\right), 5.4(1 \mathrm{H}$, septet, $J 6.3$, $\left.\mathrm{C} H\left(\mathrm{CH}_{3}\right)_{2}\right), 7.01(1 \mathrm{H}, \mathrm{d}, J 16.4, H-2 '), 7.26-7.37(2 \mathrm{H}, \mathrm{m}, H-4 "$ and $H-5 "), 7.43(1 \mathrm{H}, \mathrm{d}, J 6.8, H-$ 6"), $7.51(1 \mathrm{H}, \mathrm{dd}, J 8$ and 4.5, $H-5), 7.54(1 \mathrm{H}, \mathrm{s}, H-2 "), 7.82(1 \mathrm{H}, \mathrm{d}, J 16.4, H-1$ '), $8.1(1 \mathrm{H}, \mathrm{d}, J$ 8.2, H-4) and $8.69(1 \mathrm{H}, \mathrm{d}, J 4.1, H-6) \mathrm{ppm} ; \delta_{\mathrm{C}} 21.43\left(\mathrm{OCH}\left(\mathrm{CH}_{3}\right)_{2}\right), 69.69\left(\mathrm{OCH}\left(\mathrm{CH}_{3}\right)_{2}\right), 124.65$ $(C-6 "), 125.22\left(C-1^{\prime}\right), 125.62(C-5), 126.38\left(C-2^{\prime \prime}\right), 127.96,129.58$ (C-4" and $\left.C-5 "\right), 131.5\left(C-2^{\prime}\right)$, 133.56 (C-3), 134.34 (C-3"), 134.89 (C-4), 138.01 (C-1"), $147.45(C-2), 147.51(C-6)$ and 164.8 $\left(\mathrm{CO}_{2}-i \mathrm{Pr}\right) \mathrm{ppm}$. HRMS $\mathrm{m} / z$ 302.0960. Calc. for $\left[\mathrm{C}_{17} \mathrm{H}_{16} \mathrm{ClNO}_{2}+\mathrm{H}\right]^{+}: 302.0948$.

Isopropyl (Z)-3-(2-(3-chlorophenyl)ethenyl)pyridine-2-carboxylate ( $Z$ )-36 was obtained as an oil that had $v_{\max }(\mathrm{N}) 3059,2962,2920,2848,1716,1630,1592,1560,1466,1373,1298,1261$, $1184,1144,1105,1084,962,918,864,827,796,752,731,710,685$ and $654 \mathrm{~cm}^{-1} ; \delta_{\mathrm{H}} 1.41(6 \mathrm{H}$, d, J 5.8, $\left.\mathrm{CH}\left(\mathrm{CH}_{3}\right)_{2}\right), 5.31\left(1 \mathrm{H}\right.$, septet, $J$ 6.2, $\left.\left.\mathrm{CH}\left(\mathrm{CH}_{3}\right)_{2}\right), 6.67(1 \mathrm{H}, \mathrm{d}, J 12.4, H-2)^{\prime}\right), 6.89(1 \mathrm{H}, \mathrm{d}, J$ 7.3, $H$-4"), 7.02 (1H, d, $\left.J 12.4, H-1^{\prime}\right), 7.04-7.09$ (2H, m, $H-2 "$ and $\left.H-5 "\right), 7.12(1 \mathrm{H}, \mathrm{dd}, J 8$ and 1.4, $H$-6"), $7.22(1 \mathrm{H}, \mathrm{dd}, J 7.7$ and 4.8, $H-5), 7.49(1 \mathrm{H}, \mathrm{dd}, J 8$ and $1.5, H-4)$ and $8.61(1 \mathrm{H}, \mathrm{dd}, J$ 4.4 and 1.5, $\mathrm{H}-6) \mathrm{ppm} ; \delta_{\mathrm{C}} 21.35\left(\mathrm{CH}\left(\mathrm{CH}_{3}\right)_{2}\right), 69.29\left(\mathrm{CH}\left(\mathrm{CH}_{3}\right)_{2}\right), 125.02(\mathrm{C}-5), 126.82(\mathrm{C}-4 ")$, 126.98 (C-6"), 128.3, 128.59, 129.07 (C-1', $C-2^{\prime \prime}$ and $\left.C-5^{\prime \prime}\right), 129.4\left(C-2^{\prime}\right), 133.71,133.76(C-3$ and $C$-3"), $137.37(C-1 "), 138.65(C-4), 146.99(C-2), 148.04(C-6)$ and $164.91\left(C_{2}-i \mathrm{Pr}\right) \mathrm{ppm}$. HRMS $m / z$ 324.0763. Calc. for $\left[\mathrm{C}_{17} \mathrm{H}_{16} \mathrm{ClNO}_{2}+\mathrm{Na}\right]^{+}: 324.0767$.

Hydrogenation of isopropyl $(E)$ - and (Z)-3-(2-(3-chlorophenyl)ethenyl)pyridine-2carboxylates 36: isopropyl 3-(2-(3-chlorophenyl)ethanyl)pyridine-2-carboxylate (37). A mixture of the $(E)$ - and $(Z)$-stilbazoles $36(3.2 \mathrm{~g} ; 10.6 \mathrm{mmol})$, in ethyl acetate $(40 \mathrm{~mL})$ with $5 \%$ $\mathrm{Pd} / \mathrm{C}$ catalyst $(150 \mathrm{mg}$ ) was hydrogenated at 1 atm until uptake of hydrogen had ceased ( $c a .48$ h). Removal of catalyst and solvent yielded isopropyl 3-(2-(3-chlorophenyl)ethanyl)pyridine-2carboxylate $37(2.94 \mathrm{~g} ; 91 \%)$ as an oily solid that could not be satisfactorily recrystallised but that had mp 41-43 ${ }^{\circ} \mathrm{C}, v_{\max }(\mathrm{N}) 3051,2981,2935,2872,1722(\mathrm{C}=\mathrm{O}), 1599,1572,1479,1450$, 1439, 1387, 1375, 1354, 1336, 1298, 1232, 1194, 1182, 1146, 1107, 1095, 999, 918, 891, 866, 796, 783, 717, 702, 685 and $667 \mathrm{~cm}^{-1} ; \delta_{\mathrm{H}} 1.46\left(6 \mathrm{H}, \mathrm{d}, J 6, \mathrm{CH}\left(\mathrm{CH}_{3}\right)_{2}\right), 2.94\left(2 \mathrm{H}, \mathrm{m}, H-2^{\prime}\right), 3.19$ $\left(2 \mathrm{H}, \mathrm{m}, H-1\right.$ '), $5.36\left(1 \mathrm{H}\right.$, septet, $\left.J 6.4, \mathrm{CH}\left(\mathrm{CH}_{3}\right)_{2}\right), 7.06$ (1H, dt, $J 6.6,1.9$ and 1.9, H-6"), 7.17- 
$7.25(3 \mathrm{H}, \mathrm{m}, H-2 ", H-4 "$ and $H-5 "), 7.34(1 \mathrm{H}, \mathrm{dd}, J 7.8$ and 4.7, $H-5), 7.50(1 \mathrm{H}, \mathrm{dd}, J 8$ and 1.5 , $H-4)$ and $8.61(1 \mathrm{H}, \mathrm{dd}, J 4.8$ and $1.2, H-6) \mathrm{ppm} ; \delta_{\mathrm{C}} 21.37\left(\mathrm{CH}\left(\mathrm{CH}_{3}\right)_{2}\right), 34.31\left(C-1^{\prime}\right), 36.53\left(C-2^{\prime}\right)$, $69.38\left(C \mathrm{H}\left(\mathrm{CH}_{3}\right)_{2}\right), 125.28(C-5), 125.97,126.31,128.19,129.25(C-2 ", C-4 ", C-5 "$ and $C-6 ")$, 133.72 (C-3"), 137.28 (C-3), 139.29 (C-4), 142.48 (C-1"), $146.59(C-6), 147.36(C-2)$ and 164.97 $\left(\mathrm{CO}_{2} i\right.$-Pr) ppm. HRMS $\mathrm{m} / z$ 304.1074. Calc. for $\left[\mathrm{C}_{17} \mathrm{H}_{18} \mathrm{ClNO}_{2}+\mathrm{H}\right]^{+}: 304.1104$.

Hydrolysis of isopropyl 3-(2-(3-chlorophenyl)ethanyl)pyridine-2-carboxylate 37 to 3-(2-(3chlorophenyl)ethanyl)pyridine-2-carboxylic acid (15). The isopropyl ester 37 (2.7 g; 8.89 mmol $)$ was dissolved in ethanol $(10 \mathrm{~mL})$ with sodium hydroxide $(0.7 \mathrm{~g} ; 17.5 \mathrm{mmol})$ in water $(50$ $\mathrm{mL}$ ) and the contents of the flask were refluxed during $5 \mathrm{~h}$. After this time the solution was acidified using $1 \mathrm{M} \mathrm{HCl}$ and extracted with chloroform. The extract was washed with brine, dried, filtered and evaporated to give a colourless solid that was recrystallised from ethyl acetate to afford the acid $15(2.1 \mathrm{~g} ; 90 \%)$.

Intramolecular cyclisation of the acid 15: 8-chloro-6,11-dihydro-5 $\mathrm{H}$ benzo[5,6]cyclohepta[1,2-b]pyridin-11-one (7). The acid $15(0.34 \mathrm{~g})$ was converted into the acyl chloride using thionyl chloride, and this was cyclised according to the published ${ }^{9}$ procedure using aluminium chloride as catalyst but with dichloromethane replacing carbon disulfide as solvent to yield the tricyclic ketone 7 (40\%), m.p. 106-107 ${ }^{\circ} \mathrm{C}\left(\mathrm{CHCl}_{3}-\right.$ hexane) (lit. ${ }^{9} 100-101$ $\left.{ }^{\circ} \mathrm{C}\right), v_{\max }(\mathrm{N}) 2927,2855,1664,1644,1584,1555,1453,1408,1377,1356,1330,1294,1229$, $1212,1191,1166,1150,1087,945,907,864,838,807,794,732$ and $681 \mathrm{~cm}^{-1} ; \delta_{\mathrm{H}}\left(\mathrm{DMSO}-d_{6}\right)$ 3.11-3.18 $(2 \mathrm{H}, \mathrm{m}, H-5), 3.2-3.26(2 \mathrm{H}, \mathrm{m}, H-6), 7.47(1 \mathrm{H}, \mathrm{dd}, J 8.5$ and $2, H-9), 7.51(1 \mathrm{H}, \mathrm{s}, H-$ 7), $7.52(1 \mathrm{H}, \mathrm{dd}, J 8$ and $5, H-3) 7.85(1 \mathrm{H}, \mathrm{dd}, J 8$ and $2, H-4) 7.87(1 \mathrm{H}, \mathrm{d}, J 8.5, H-10)$ and 8.59 $(1 \mathrm{H}, \mathrm{dd}, J 4.8$ and $1.7, H-2) \mathrm{ppm} ; \delta_{\mathrm{C}} 30.83(C-5), 33.57(C-6), 126.32(C-3), 126.85(C-9)$, 130.02 (C-7), 131.92 (C-10), $135.58(C-15), 136.47(C-13), 137.44(C-8), 137.46(C-4), 144.15$ $(C-14), 148.1(C-2), 154.45(C-12)$ and $193.52(C-11)$ ppm. HRMS $m / z$ 244.0546. Calc. for $\left[\mathrm{C}_{14} \mathrm{H}_{10} \mathrm{ClNO}+\mathrm{H}\right]^{+}: 244.0529$.

\section{Acknowledgements}

We thank the University of Dublin, Trinity College, for financial support to M. C. E., and Dr John O'Brien for the NMR spectra.

\section{References and Notes}

1. In the United States of America.

2. In several EU states. 
3. See, for example, Hall, S. S. "Claritin and Schering-Plough: A Prescription for Profit", New York Times on the web, 11/03/2001, available from http://www.nytimes.com/2001/03/11/magazine/the-claritin-effect-prescription-forprofit.html?module $=$ Search\&mabReward=relbias\%3As

4. Barnett, A.; Green, M. J. Chronicles of Drug Discovery, American Chemical Society, 1993, 83.

5. Villani, F. J. Belgian Patent 647043, 1964 (to Scherico Ltd.); CA63:80576.

6. Villani, F. J. US Patent 3357 986, 1967 (to Schering Corporation); CA69:27262.

7. Villani, F. J.; Wefer, E. A.; Mann, T. A.; Mayer, J.; Peer, L.; Levy, A. S. J. Heterocycl. Chem., 1972, 9, 1203. http://dx.doi.org/10.1002/jhet.5570090602

8. Villani, F. J. US Patent 4282 233, 1981 (to Schering Corporation); CA95:203761.

9. Villani, F. J.; Daniels, P. J. L.; Ellis, C. A.; Mann, T. A.; Wang, K.-C. J. Heterocycl. Chem. 1971, 8, 73. http://dx.doi.org/10.1002/jhet.5570080115

10. Schumacher, D. P.; Murphy, B. L.; Clark, J. E.; Tahbaz, P.; Mann, T. A. J. Org. Chem. 1989, 54, 2242. http://dx.doi.org/10.1021/jo00270a041

11. Poirier, M.; Chen, F.; Bernard, C.; Wong, Y.-S.; G. Wu, G. Org. Lett. 2001, 3, 3795. http://dx.doi.org/10.1021/ol016809d

12. Chen, X.; Poirier, M.; Wong, Y.-S.; Wu, G.-Z. US Patent 5998 620, 1999 (to Schering Corporation), CA132:12263.

13. Bernard, C.; Casey, M.; Chen, F. X.; Grogan, D. C.; Poirier, M.; Williams, R. P.; Wong, Y.S.; Wu, G. G. WO 00/30589, 2000 (to Schering Corporation), CA133:4603.

14. Bernard, C.; Casey, M.; Chen, F. X.; Grogan, D. C.; Poirier, M.; Williams, R. P.; Wong, Y.S.; Wu, G. G. US 6372 909, 2002, (to Schering Corporation), CA136:309859.

15. Schickaneder, H.; Nikolopoulos, A.; Kocher, C.; Mulcahy, D. WO 00/05215, 2000, (to Russinsky Ltd.), CA132:107883.

16. Cannata, V.; Cotarca, L.; Michieletto, I.; Poli, S. WO 03/040140, 2003, (to Zambon Group S. P. A.) CA 138:385421

17. Schenck, L. M.; Bailey, J. R. J. Am. Chem. Soc. 1940, 62, 1967. http://dx.doi.org/10.1021/ja01865a019

18. Schenck, L. M.; Bailey, J. R. J. Am. Chem. Soc. 1941, 63, 1365. http://dx.doi.org/10.1021/ja01850a066

19. Lindenstruth, A. F.; Vanderwerf, C. A. J. Am. Chem. Soc. 1949, 71, 3020. http://dx.doi.org/10.1021/ja01177a021

20. Wibaut, J. P.; Boer, H. Rec. Trav. Chim. Pays-Bas 1955, 74, 241.

21. Boer, H.; Sixma, F. J. L.; Wibaut, J. P. Rec. Trav. Chim. Pays-Bas 1951, 70, 509.

22. Sixma, F. J. L. Rec. Trav. Chim. Pays-Bas 1952, 71, 1124. 
23. Sturrock, M. G.; Cline, E. L.; Robinson, K. R.; Zercher, K. A. US 2964 529, 1960, (to Koppers Co. Inc.), CA55:59566.

24. Andreozzi, R.; Insola, A.; Caprio, V.; D’Amore, M. G. Water Res. 1991, 25, 655. http://dx.doi.org/10.1016/0043-1354(91)90040-W

25. Callighan, R. H.; Wilt, M. H. J. Org. Chem. 1961, 26, 4912. http://dx.doi.org/10.1021/jo01070a032

26. O'Murchu, C. Synthesis 1989, 880. http://dx.doi.org/10.1055/s-1989-27423

27. Taddie, D.; Poriel, C.; Moody, C. J. Arkivoc 2007, (xi), 56.

28. Pappas, J. J.; Keaveny, W. P.; Gancher E.; Berger, M. Tetrahedron Lett. 1966, 36, 4273. Taddie et al. ( $c f$. reference 26) also obtained superior results when using this reducing agent.

29. Burke, S. D.; Danheiser. R. L. (eds.), Handbook of Reagents for Organic Synthesis, Wiley, Chichester, 1999, 274.

30. Marley, K. A.; Larson, R. A.; Stapleton, P. L.; Garrison, W. J.; Klodnycky, C. M. Ozone: Science and Engineering, 1987, 9, 23. http://dx.doi.org/10.1080/01919518708552386

31. Larson, R. A.; Garrison, W. J.; Marley, K. A. Tetrahedron Lett. 1986, 27, 3987. http://dx.doi.org/10.1016/S0040-4039(00)84891-1

32. Ornstein, P. L.; Schaus, J. M.; Chambers, J. W.; Huser, D. L.; Leander, J. D.; Wong, D. T.; Pascal, J. W.; Jones, N. D.; Deeter, J. B. J. Med. Chem. 1989, 32, 827. http://dx.doi.org/10.1021/jm00124a015

33. Kaufmann A.; Rothlin, E. Chem. Ber, 1916, 49, 581.

34. Armarego, W. L. F.; Milloy, B. A.; Sharma, S. C. J. Chem. Soc., Perkin Trans. 1 1972, 2485. http://dx.doi.org/10.1039/p19720002485

35. Shchukina, M. N.; Savitskaya, N. V. Zh. Obshchei Khim. 1952, 22, 1218.

36. Acheson R. M.; Harrison, D. R. J. Chem. Soc. C 1970, 1764.

37. Lee, G. D.; Brown, K.C.; Karaman, H. Can. J. Chem. 1986, 64, 1054; Tchilibon, S.; Kim, S.K.; Gao, Z.-G.; Harris, B. A.; Blaustein, J. B.; Gross, A. S.; Duong, H. T.; Melman, N.; Jacobson, K. A. Bioorg. Med. Chem. 2004, 12, 2021.

38. The melting point of the acid $\mathbf{1 5}$ does not appear to have been reported in either the academic or the Patent literature. 